\title{
Parazita folyóiratok, a tudományos világ élősködői
}

\author{
Juhász Attila \\ Debreceni Egyetem, Informatikai Tudományok Doktori Iskola \\ juhaszattila93@gmail.com \\ Szabó Dóra \\ Debreceni Egyetem, Informatikai Kar, Könyvtártudományi Tanszék \\ szabog6dora@gmail.com
}

The emergence of open access undoubtedly had a positive impact on the efficiency of scientific communication. Among other things it eliminated the spatial and temporal constraints, improved international cooperation, and caused the shortening of research times. However, parallel to this, predatory publications, that pose a threat to the scientific world due to their profit oriented pseudo-scientific activity, also appeared. Our paper discusses ongoing research that examines the scientific visibility of educators in domestic institutions of higher education and their relation to predatory journals.

Keywords: Open Access, predatory journals, scientific visibility

\section{Bevezetés}

Az Open Access (OA), azaz a nyilt hozzáférés megjelenésével a tudományos tartalmak digitális formában, online elérhetővé váltak. Ezen publikációk jogi korlátozás nélkül, a megfelelö hivatkozásokkal szabadon felhasználhatóak mindenki számára. Ebböl következett, hogy felgyorsult a tudományos kommunikáció sebessége, hiszen a legfrissebb kutatási eredmények bárhol, bárki számára elérhetővé váltak, ezáltal sikerült áthidalni a korábbi tér-és idöbeli nehézségeket, ami előnyös lehet a nemzetközi kutatások hatékony összehangolása esetében is. Az elektronikus megjelenésnek köszönhetően nőtt a szerzök olvasottsága, mely a legtöbb esetben megmutatkozott az idézettségükön is. Ugyanakkor a pozitiv hozományok mellett a negativumokról sem feledkezhetünk meg. Megjelentek az úgynevezett ragadozó kiadványok, melyek magukat tudományos kiadványként tüntetik fel, viszont valójában profitorientált, a tudományosságot nélkülöző lapokról van szó. A jelenlétük azért is ártalmas, mert általuk számtalan áltudományos mü válik elérhetővé bárki számára, ezáltal csorbítva a tudományosságba vetett hitet. Alább a jelenleg folyamatban lévő kutatásunkat ${ }^{1}$ ismertetjük, amelyben a hazai egyetemek oktatóinak tudományos láthatóságával és a ragadozó kiadványokhoz füződő viszonyával foglalkozunk.

\footnotetext{
1 https://docs.google.com/forms/d/19gJpNv-Hk2JP-iVh4YBqolcbzdhcracV204dhuPPibo/ edit?usp=forms_home (2019. 06.30.)
} 


\section{A ragadozó folyóiratok}

A parazita, vagy más néven ragadozó folyóiratok² (angolul predatory journals) a tudományos világ élősködőiként jelentek meg az elektronikus publikációk térhóditásával. A ragadozó kiadványok tudományos folyóiratokálcáját öltik magukra, nívós lapként tüntetik fel magukat, viszont nem válogatják meg a publikálandó cikkek körét, a megfelelő dijak fejében bármit közzétesznek. A szerkesztőbizottság tagjait az interneten toborozzák, a kutatókat pedig kéretlen levelekkel bombázzák, hogy náluk tegyék közzé legújabb eredményeiket. A megtévesztés módszerét alkalmazzák: nivós lapokhoz hasonló nevet és megjelenést választanak. Mivel nem ellenörzik a cikkeket, nem felelnek meg a tudományos folyóirat-kiadás szakmai követelményeinek. Tevékenységüksúlyoskárokatokoz, mivelcsorbítjaatudományos világba vetett hitet. Ez azért is jelentős probléma, mert a nyilt hozzáférés korában már bárki hozzáférhet ezen ellenörizetlen cikkekhez, amelyek, megtéveszthetik azon olvasókat, akik hiteles információhoz szeretnének hozzájutni. Tevékenységük egyik táptalaja a napjainkban jól ismert publish or perish elv, ${ }^{3}$ miszerint a tudományos elömenetelhez nélkülözhetetlenné vált a megfelelő számú publikáció megléte, azaz létrejött a publikálási kényszer. Az említett elv szerint, aki nem publikál az nem juthat elöre a tudományos ranglétrán. A ragadozó folyóiratok természetesen erre sem kínálnak igazi megoldást, hiszen, ha egy kiadóról kiderül, hogy parazita tevékenységet folytat, abban az esetben a szerzők ott megjelentetett cikkeit nem fogadják el a tudományos elörehaladásukhoz, illetve a pályázataikhoz. A ragadozó tevékenység először Jeffrey Beall ${ }^{4}$ amerikai könyvtárosnak szúrt szemet, aki el is készitette 2011-ben az általa parazitának vélt kiadványok listáját (Beall-lista) ${ }^{5}$, illetve folyamatosan frissitette azt. A munkáját 2017-ben kénytelen volt befejezni az öt ért folyamatos támadások miatt, a lista pedig elavulttá vált, hiszen az ilyen jellegü kiadványok száma egyre csak nő. Ezért is fontos a megfelelö körültekintés, mielött a szerzők kiadnák kézirataikat a kezükböl. Ehhez szükség van a ragadozó lapok ismérveinek alapos ismeretére, valamint érdemes a DOAJ-ban ${ }^{6}$ is megnézni, hogy szerepel-eottazadottkiadvány, hiszen ottmegtalálhatóakazindexeltOAkiadványok.

\section{A kutatók és a tudományos láthatóságuk vizsgálata}

Mint a fentebb emlitett publish or perish elvből kiderült, a megfelelő számú publikáció elengedhetetlen ahhoz, hogy a kutató elöre juthasson a szakmai ranglétrán. Ajelenleg is folyó, terveink szerint reprezentativ mintát elérő elektronikus felmérésünkben (elektronikus Google kérdőiv), melyre jelenleg 500 válaszadónk van, arra keressük a választ, hogy mi motiválja a hazai felsőoktatásban az oktatókat.

\footnotetext{
$2 \quad$ Holl András, Parazita folyóiratok (predatory journals), URL: https://Www.mtmt.hu/system/files/parazita_folvoiratok.pdf (2019. 06. 30.)

3 Erzsebet, Dani: How "Publish or Perish" Can Become "Publish and Perish" in the Age of Objective Assessment of Scientific Quality URL: http://www.iilsci.org/journal/CV\$/sci/pdfs/IP052LL18.pdf (2019. 06. 30.)

4 Interjú Jeffrey Beallel, Könyv, Könyvtár, Könyvtáros, URL: http://ki2.oszk.hu/3k/2016/09/atudomany-eloskodoi-denveri-beszelgetes-jeffrey-beall-lel//2019. 07. 21.)

$5 \quad$ Alan Burdick: "Paging Dr. Fraud": The Fake Publishers That Are Ruining Science, The New Yorker 5 BEALL'S LIST OF PREDATORY JOURNALS AND PUBLISHERS URL: https://beallslist.weebly.com/ (2019. 03. 11.)

6 Directory of Open Access Journals https://doaj.org/ (2019. 06. 30.)
} 
Ez a kérdés azért releváns, mert aki motivált az elörejutás felé, az feltehetően szeretné, ha a tudományos munkája szélesebb körben lenne elérhető, hiszen így növelhető az idézettsége, amire az OA folyóiratok tökéletes lehetőséget nyújtanak. Feltehetően a motivált válaszadók a saját intézményük repozitóriumán túl egyéb felületeken is közzéteszik a munkáikat (pld. Google Scholar, Research Gate, esetleg személyes honlap). Hazánkban az elektronikus közzététel egyik legismertebb felületea MagyarTudományos Müvek Tára (MTMT) ${ }^{7}$, amely nem repozitórium, hanem nemzeti bibliográfiai adatbázis, melynek müködése törvény által is szabályozott. A kutatásunk során azt is megvizsgáljuk, hogy a megkérdezettek mekkora része gondozza rendszeresen ezen felületét. Ez azért is fontos, mert itt a szerzőknek lehetöségük van arra, hogy könnyedén összeállithassanak bibliográfiákat, publikációs listákat, amelyeket felhasználhatnak pályázatok során is, mely szintén összefüggésben állhat a motiváció mértékével. Továbbá vizsgáljuk azt is, hogy a megkérdezettek mekkora része publikált már nyilt hozzáférésű folyóiratban, illetve, ha esetleg még nem, akkor nyitott-e ezen megjelentetési forma irányába, vagy inkább tartózkodnak töle. A felmérés egyik legfontosabb kérdése pedig azokhoz szól, akik már publikáltak nyiltt hozzáférésü kiadványban, esetükben ugyanis azt szeretnénk megtudni, hogy tapasztalták-e a tudományos láthatóságuk növekedését a nyilt hozzáférésnek köszönhetöen. A nemzetközi tapasztalat szerint egyértelmüen megállapitható, hogy nő azon kutatók idézettsége ${ }^{8}$, akik szabadon elérhetővé teszik eredményeiket. Úgy véljük, hogy ez a hazai válaszadók esetében sem lesz másként.

Továbbá szeretnénk megtudni, hogy a szerzök rendelkeznek-e ORCID9azonositóval. Ennek az a lényege, hogy a szerzök egyértelmüen azonosithatók legyenek, mivel gyakoriak a névazonosságok, amelyek problémát okozhatnak a teljesitménymérés folyamatában. Az utóbbi idöben több kiadó is ehhez a dijmentesen létrehozható azonositóhoz köti a kéziratok befogadását.

\section{A kutatók és a ragadozó folyóiratok kapcsolatának vizsgálata}

A tudományos láthatóságra vonatkozó kérdéseket követően a felmérés túlnyomó részében a hazai felsőoktatási dolgozókés a ragadozó folyóiratok közötti kapcsolatot vizsgáljuk.

Először azt szeretnénk megtudni, hogy a megkérdezettek mekkora része találkozott már a tudományos munkája során ilyen jellegü kiadványokkal, vagyis a válaszadók mekkora részét keresték meg valamilyen módon. Úgy véljük, hogy a többség már kapott felkérést ragadozó kiadványoktólvalamilyen formában. Ugyanakkor fontos, hogy a szerző el tudja dönteni az adott kiadványról, hogy az valóban parazita tevékenységet folytat-e, melyhez szükség van a megfelelő kritikai érzéken túl arra is, hogy a kutatók ismerjék ezen kiadványok ismérveit. Ennek megismerésére a kitöltés során egy listából kell kiválasztania a lehetséges ismérveket a megkérdezetteknek. Előzetes hipotéziseink szerint a válaszadók nagy többsége képes felismerni az árulkodó jeleket, azaz képes

\footnotetext{
7 Magyar Tudományos müvek Tára, URL: https://www.mtmt.hu/ (2019. 06. 30.)

8 Gemma Hersh, Andrew Plume: Citation metrics and open access: what do we know?, URL: https://www.elsevier.com/connect/citation-metrics-and-open-access-what-do-we-know (2019. 03. 11.) 
döntést hozni egy-egy kiadvány jellegéröl. A kérdöív további szakaszában Likert-skála segítségével kivánjuk megismerni a válaszadók véleményét.

A ragadozó folyóiratokra vonatkozó kérdések sorában az első arra vonatkozik, hogy a válaszadó mennyire tartja veszélyesnek a kiadványokat a tudományos világra tekintve. Úgy véljük, hogy a megkérdezettek többsége valós veszélyként tekint ezekre a kiadványokra, hiszen súlyosan csorbitják a tudományba vetett hitet, illetve azontúl, hogy gyakran valótlan információkat közölnek, akár érdemtelen elönyhöz is juttathatják azokat, akik ilyen jellegü kiadványokban publikálnak a tisztességes utat választó szerzőkhöz képest. Aki nem szeretne ezen kiadványok csapdájába esni, fontos, hogy alaposan járjon utánuk. Erre vonatkozik a következö kérdés, miszerint alaposan utánajár-e a szerző az egyes kiadványoknak, mielőtt ott megjelentetné cikkeit. Szeretnénk azt is megtudni, hogy a válaszadók hogyan vélekednek, arról, hogy társaik képesek-e eldönteni egy-egy folyóiratról, hogy az áltudományos tevékenységet végez-e. Úgy gondolom, hogy a válaszadók többsége már kapott felkérést ilyen kiadványoktól, illetve mint fentebb az ismérvek kiválasztásánál is részleteztük, feltehetően el tudják dönteni, hogy tisztességes OA folyóirattal van-e dolguk.

A ragadozó folyóiratok veszélyt jelentenek áltudományos tevékenységükkel a tudományos világra, viszont szeretnénk megtudni, hogy a válaszadók tulajdonítanak-e nekik esetleg valamiféle előnyt. Ezen előny lehet akár az is, hogy gyors a publikációs folyamat, hiszen itt nincs valós szakmai bírálat, ebböl adódik az is, hogy hamar kerülnek publikálásra a cikkek. Természetesen ez nem tekinthető a szó szoros értelmében vett elönynek, hiszen ez éppen a minöség rovására megy. Ebböl a kérdésböl kiindulva arra is keressük a választ, hogy a megkérdezettek szerint egyes kutatók a személyes elörehaladásuk érdekében akár önszántukból is publikálnának-e ragadozó folyóiratokban. Ezt mindenképpen elitélendőnek tartjuk, viszont mint lehetöséget nem lehet kizárni, hiszen a valós eredmények hiányában elegendő a megfelelö közzétételi dij megfizetése és a kutató máris több nemzetközi cikkel rendelkezhet, amelyet feltüntethet pályázatok benyújtása során, vagy a tudományos elömenetelét biztosithatja a segitségükkel. Viszont, mint korábban írtuk, amennyiben egy folyóiratról kiderül, hogy ragadozó tevékenységet folytat, abban az esetben az ott megjelentetett kiadványokat nem lehet elszámolni semmilyen formában sem, illetve szükséges lenne, ezen tartalmak eltávolítása az elektronikus felületekről. ${ }^{10}$ Amennyiben egy szerző ilyen jellegü kiadvánnyal találkozik, abban az esetben azt jelentheti az MTMT felé is. ${ }^{11}$

Továbbá vizsgáljuk, hogy a kutatók kellően tájékozottak-e a ragadozó lapokban történő publikálás veszélyeiröl. Ezek nem csupán a tudományos világ hitelességére jelentenek veszélyt, hanem magukra a szerzőkre is, mivel az itt megjelentetett

\footnotetext{
10 The gth International Conference on Society and Information Technologies: Proceedings Konferencia helye, ideje: Orlando (FL), Amerikai Egyesült Államok, 2018.03.13-2018.03.16. Winter Garden (FL): International Institute of Informatics and Systemics (IIIS), 2018. 43-44P (ISBN:9781941763742) Jeffrey, Beall: Predatory journals: ban predators from the scientific record, Nature, 534 (2016), 326p 
munkák nem közölhetőek újra valódi tudományos lapban, tulajdonképpen a semmire fizetnek publikálási költséget, valamint ezen kiadók megtartják a szerzői jogokat is. ${ }^{12}$ A parazita folyóiratokban a publikálókat két csoportra lehet bontani. Az egyik, lényegesen nagyobb részük gyanútlan áldozat, akik nem szándékosan publikálnak a kiadványokban, míg a másik, kisebbik részük tisztában van a kiadó tevékenységével. Mindkét csoport tagjaira érvényesek viszont a fentebb ismertetett hátrányok, igy érdemes alaposan utánajárni a kiadványoknak.

Ahhoz, hogy a káros tevékenységet folytató kiadók kiszoruljanak a tudományos világ piacáról, véleményem szerint egységes fellépés kellene. A válaszadók véleményét is szeretnénk megismerni a kérdést illetően, és arra számitunk, hogy a többség szintén egyetért az összehangolt fellépés szükségességét illetően. A kérdőív végén arra vagyunk kiváncsiak, hogy az oktatók mit tartanak a nyilt hozzáférés előnyeinek, illetve hátrányainak. Azt gondolom, hogy a válaszadók az ingyenességet fogják a legnagyobb mértékben kiemelni, míg hátrányként a minöségi fenntartások túlsúlyba kerülésére számítok, ami összefüggésben állhat kutatásom tárgyával, a ragadozó folyóiratok egyre növekvő térnyerésével.

A kutatás tavasz végi lezárása után, a kapott válaszok kielemzését követően fogunk tudni pontos képet adni a tanulmányban felmerülö kérdésekre, melyek azt gondolom, hogy igencsak aktuálisak és a tudományos világ összes résztvevőjét érintik valamilyen módon.

\section{4. Összegzés}

A jelenleg is zajló, reményeink szerint a reprezentatív mintát elérő kutatást két részre oszthatjuk, az első fele a kutatók tudományos láthatóságát vizsgálja, miszerint mennyire motiváltak, illetve amennyiben fontosnak érzik, hogy szélesebb körbe juttathassák el eredményeiket, abban az esetben mit tesznek érte. Illetve szeretnénk megtudni, hogy akik már eddig is jelentettek meg nyilt hozzáférésü cikkeket, ők tapasztalták-e a tudományos láthatóságuk növekedését. A felmérés második, nagyobb része a ragadozó folyóiratokkal foglalkozik. Arról szeretnénk átfogó képet kapni, hogy a válaszadók mekkora része találkozott már ilyen jellegü kiadvánnyal, illetve képesek-e eldönteni egy esetleges megkeresés esetén azt, hogy az adott kiadvány valóban OA jellegü, vagy csupán áltudományos tevékenységet folytat. A Likert-skálás mérések lehetőséget adnak arra, hogy alaposabban megismerhessük a kitöltök véleményét a kérdéskörben, illetve átfogó képet adhassunk a hazai helyzetről. A kutatás lezárása 2019 őszén várható, ezt követően kezdődhet el a kapott eredmények kiértékelése.

\section{Köszönetnyilvánítás:}

A kutatást az "Integrált kutatói utánpótlás-képzési program az informatika és számítástudomány diszciplináris területein" (EFOP-3.6.3-VEKOP-16-2017-00002) cimü projekt támogatta. A projekt az Európai Unió támogatásával, az Európai Szociális Alap társfinanszírozásával valósult meg.

12 Farkas Boglárka: Open Access források, a publikálás veszélyei, parazita folyóiratok URL: https://slideplayer.hu/slide/11936495/ (2019. 03. 11.) 